\title{
Altitudinal movements and conservation of Bare-necked Umbrellabird Cephalopterus glabricollis of the Tilarán Mountains, Costa Rica
}

JOHEL CHAVES-CAMPOS, J. EDGARDO ARÉVALO and MARIAMALIA ARAYA

\begin{abstract}
Summary
Bare-necked Umbrellabird Cephalopterus glabricollis is endemic to Costa Rica and western Panama. It eats fruit, breeding at high elevations $(\geq 800 \mathrm{~m})$ and migrating to lower elevations during the non-breeding season. Using data from transect counts and radio-telemetry, we monitored bird movements in a protected area (Monteverde-ArenalSan Ramón reserves) in the Tilarán Mountains, Costa Rica. We also monitored fruit abundance along an altitudinal gradient to explore the potential relationship between bird movements and the abundance of the fruits this species consumed. The presence and abundance of umbrellabirds at high elevations $(1,400 \mathrm{~m})$ during the breeding season (March-June) coincided with the highest peak of fruit abundance. The presence of umbrellabirds in the lowlands $(400 \mathrm{~m})$ during the non-breeding season overlapped with the period of highest fruit abundance at these elevations. At middle elevations, bird presence and abundance did not correlate with fruit abundance. Radio-tagged birds left the protected area during the non-breeding season and there were no umbrellabirds inside the protected area during this period. Habitats where this species bred were well represented in the protected area but the habitat where they spent the non-breeding season was poorly represented, and was not adequately protected. This represents a potential threat to this species in the Tilarán Mountains.
\end{abstract}

\section{Introduction}

Migratory bird populations are especially vulnerable to habitat modifications caused by human activities (Terborgh 1992). In the tropics, altitudinal migrants are particularly affected by habitat fragmentation because some species avoid crossing open areas along altitudinal gradients that they use during their migratory cycle (Stiles 1985, Loiselle and Blake 1991, 1992, Blake and Loiselle 2000). To ensure the conservation of such species, it is necessary to know their habitat requirements (Levey et al. 1994).

Bare-necked Umbrellabird Cephalopterus glabricollis is endemic to the Caribbean slope of Costa Rica and western Panama (Snow 1982, Stiles and Skutch 1989, Ridgely and Gwynee 1993). Several populations of this species persist in protected areas in Costa Rica (e.g. La Selva Biological Station-Braulio Carrillo National Park, Arenal National Park-Monteverde Protected Area, Guanacaste 
Conservation Area; Stiles and Levey 1994, Fogden 2000, and pers. obs.). Nevertheless, the species is considered to be at high risk of extinction in the near future due to habitat loss, and is classed as Vulnerable (BirdLife International 2000).

Bare-necked Umbrellabirds live only in forest and their diet consists mainly of fruits (Snow 1982, Stiles 1985, Stiles and Skutch 1989). They breed in montane and premontane forests (life zones according to Holdridge 1967) between March and June and spend the non-breeding season in lowland forests (Stiles 1988, Stiles and Skutch 1989, Blake et al. 199ob, Fogden and Fogden 1997). The lower altitudinal limit of the umbrellabird corresponds to the tropical wet forest life zone (Stiles 1988, Stiles and Skutch 1989, Stiles and Levey 1994). In most areas where umbrellabird populations remain, tropical wet forest has been fragmented or totally cleared (Collar et al. 1992). The effect of non-breeding habitat loss on umbrellabird populations is unknown, but it is presumably negative since this species spends at least five months of each year in the lowlands (Stiles 1988). It is likely that altitudinal migrants move in response to fruit abundance (Wheelwright 1983, Levey 1988, Blake and Loiselle 1991, Loiselle and Blake 1991). Therefore, habitat loss in the lowlands could lead to a decline in food resources during the non-breeding season, which could increase the risk of extinction.

Although Bare-necked Umbrellabird is considered at risk from extinction, it is unknown whether the protected areas in Costa Rica and Panama include all the critical habitats this species requires. The main objective of this research was to study the movements of umbrellabirds and the temporal abundance of the fruits this species consumes, and assess whether the current protected area network covers all habitats and food resources required during the bird's annual cycle.

\section{Methods}

Study area

We conducted this study on the Caribbean slope of the Tilarán Mountains, Costa Rica $\left(10^{\circ} 18^{\prime} \mathrm{N}, 84^{\circ} 45^{\prime} \mathrm{W}\right)$. Umbrellabirds have been seen in these mountains every year since 1979 (Fogden and Fogden 1997). Continuous forest ranges from 400 to $1,850 \mathrm{~m}$ above sea level within a complex of biological reserves that includes the Arenal National Park, the Monteverde Cloud Forest Preserve, the Children's Eternal Rainforest, the Alberto Ml. Brenes Biological Reserve, and other smaller reserves (approximately 40,000 ha). The protected area encompasses the following life zones (Holdridge 1967): lower montane rainforest (1,550-1,850 $\mathrm{m}$ of elevation), premontane rainforest (700-1,400 $\mathrm{m}$ ), and tropical wet forest cool transition (below $700 \mathrm{~m}$ ) (Haber 2000). The old-growth forest below $400 \mathrm{~m}$ has been cleared and replaced with pastures and plantations. The area receives heavy rainfall (mean annual precipitation between 3,600 and 8,000 mm; Haber 2000), and the dry season typically lasts from February to April (Coen 1983, Sanford et al. 1994, Clark et al. 2000). The seasonal pattern of rainfall on the Caribbean slope is similar at all altitudes (Blake and Loiselle 2000).

\section{Monitoring of altitudinal movements}

To assess temporal variation in umbrellabird abundance along the altitudinal gradient, we collected data from transect counts at four different elevation sites 

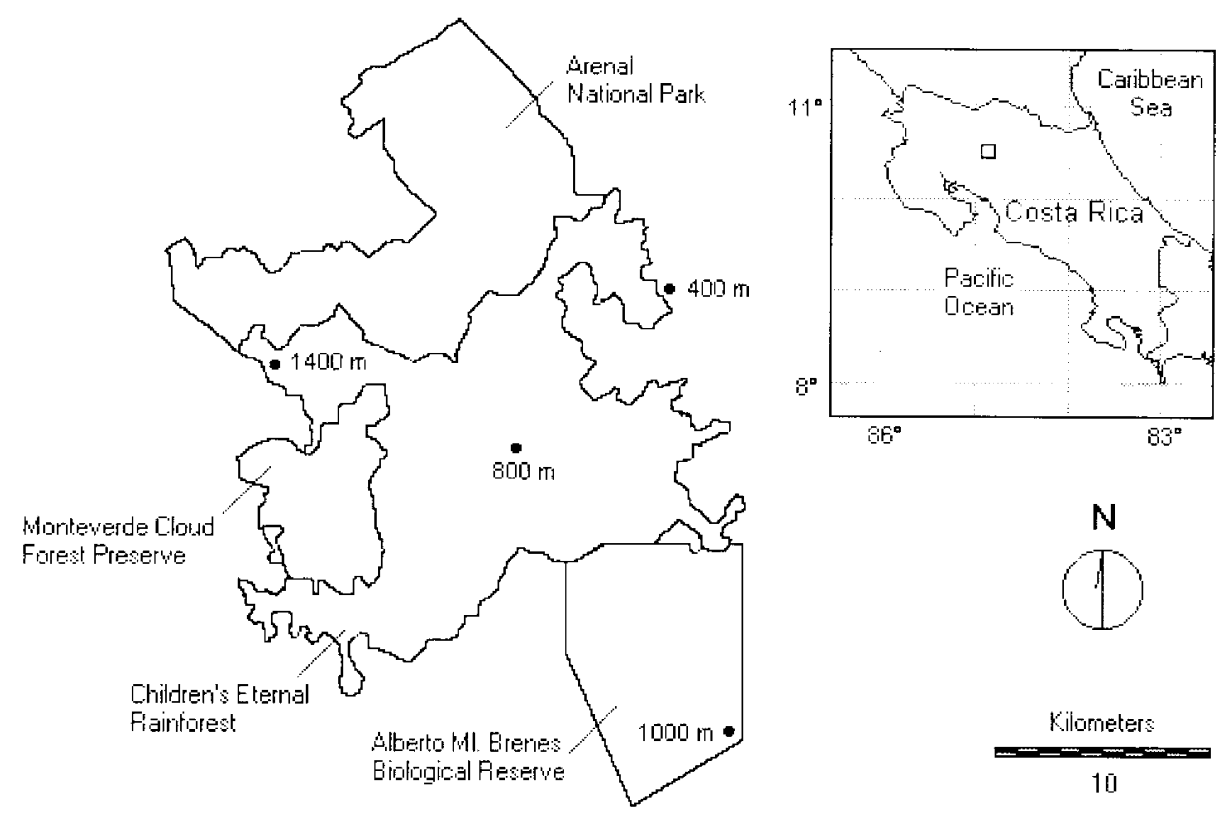

Figure 1. Study sites along the Caribbean slope of the Tilarán Mountains, Costa Rica, 1998-1999. Elevations represent lower montane rainforest (1,400 m), premontane rainforest $(1,000 \mathrm{~m}$ and $800 \mathrm{~m})$ and tropical wet forest cool transition $(400 \mathrm{~m})$.

(Figure 1). One site was located at 1,400 $\mathrm{m}$ on the limits of the lower montane rainforest life zone, two sites were established in premontane rainforest at 1,000 $\mathrm{m}$ and $800 \mathrm{~m}$, and another site at $400 \mathrm{~m}$ in tropical wet forest cool transition. The tropical wet forest cool transition site was outside the protected area system because this life zone is practically unrepresented in the reserves. We did not include higher sites because umbrellabirds have been rarely observed above $1,300 \mathrm{~m}$ in this area (Fogden and Fogden 1997).

The study was conducted between January 1998 and February 1999. At each elevation we established two transects of $2 \mathrm{~km}$ on existing trails through mature forest, for a total of eight transects along the altitudinal gradient. Bird abundance was estimated at each elevation in seven sampling periods, 6-8 weeks apart. Every sampling period comprised two days. On the first day, one of us (J.C.) walked continuously along one transect from o6hoo to oghoo and the following day the other transect was sampled using the same methodology. Bird abundance was recorded along these transects as the number of birds observed or heard during the walks. Large fruit-eating birds usually remain around fruiting trees and visit them many times a day (Wheelwright 1991). The transects were at least $2 \mathrm{~km}$ apart; so observations on one trail were probably independent of the other (Solórzano et al. 2000).

We also used radio-telemetry to identify more accurately the habitats that umbrellabirds used during their annual cycle. We captured umbrellabirds using mist-nets ( $2.6 \mathrm{~m}$ high, $121 \mathrm{~mm}$ mesh, $12 \mathrm{~m}$ wide, two shelves) placed in the canopy in a lekking area at the $1,400 \mathrm{~m}$ site during the breeding season (March- 
June 1998). Every umbrellabird caught was colour-ringed and a radio-transmitter was placed on the bird's back with a nylon harness (provided by AVM Instruments), sewn with cotton thread, in the form of a backpack. The radiotransmitters (AVM Instruments 56866) were waterproof, and the life of the batteries was estimated to be 13 months. The entire device weighed $14 \mathrm{~g}$, less than $4.5 \%$ of an average individual body mass (female $320 \mathrm{~g}$, male $450 \mathrm{~g}$; Stiles and Skutch 1989).

Movements of tagged birds were monitored using a portable receiver (AVM Instruments LA12-Q) and a hand-held " $\mathrm{H}^{\prime}$ antenna (AVM Instruments) with a detection range of $5 \mathrm{~km}$ on flat-forested land. Birds were tracked weekly in the breeding area to determine their presence during the breeding season. After the breeding season, we located radio-tagged birds every month, sometimes from cars or small planes. Locations of birds were plotted on a digital map that included forest distribution, life zones, and reserve boundaries using IDRISI-GIS (Clark University) software.

\section{Fruit abundance along the altitudinal gradient}

We sampled fruit abundance during the same periods that umbrellabird presence and abundance were recorded. Like Loiselle and Blake (1991) and Solórzano et al. (2000), we used the number of fruits as an estimate of resource availability. Employing methods described by Rosselli (1994) and Blake et al. (1990a), we counted fruits in area-based samples. We established three transects $(100 \times 2 \mathrm{~m}$ each and $100 \mathrm{~m}$ apart) placed along each trail (two trails per elevation) where umbrellabird abundance was recorded. Altogether, six transects were carried out at each elevation site. In every sampling period, one of us (J.C.) counted the number of ripe and unripe fruits (from the forest floor with binoculars) on trees whose stem and trunk were within (or at least touching) the borders of the transects. The crown area of the trees included in the transects varied, so that of every tree was calculated in order to estimate the area sampled per elevation. The total area sampled at every elevation was around $5,000 \mathrm{~m}^{2}$.

In trees with thousands of fruits (e.g. figs), fruits were counted in 10\% of the crown and extrapolated to the whole crown (Dinerstein 1986, Solórzano et al. 2000). For those species with capsular fruits, the total number of fruits per tree was multiplied by the average number of arillated seeds per capsule (Blake $e t$ al. 1990a). Hereafter, fruit abundance is presented as the number of fruits plus the number of arillated seeds.

\section{Data analysis}

Although the diet of umbrellabirds is similar to that of trogons (Trogonidae), guans (Cracidae), toucans (Ramphastidae), fruitcrows (Cotingidae), and other large birds that eat both fruit and animal food (Fogden and Fogden 1997, pers. obs.), we included only those plants whose fruits are actually consumed by Barenecked Umbrellabird according to Snow (1982), Stiles and Skutch (1989), Fogden and Fogden (1997), and personal observations. There is little information available on the diet of Bare-necked Umbrellabird in lowland forests, so at the lowland site $(400 \mathrm{~m})$ we included congeners of species consumed by umbrellabirds 
in highlands and middle elevations (montane and premontane forest), and species eaten by other large fruit-eating birds in the lowlands (e. g. guans, trogons, fruitcrows, toucans) that have similar colour, size and accessibility.

We used Spearman's rank correlation tests to examine the relationship between bird and fruit abundance at each elevation. At each elevation, the fruit counts from the six transects per sample were combined in order to have a total estimation of fruit abundance per sampling period. With an analogous purpose, we combined the bird counts from the two transects at each elevation. The total abundance of birds and fruits over the seven sampling periods was correlated within each site. The total number of fruits per sampling period was used as an estimate of fruit abundance since this kind of estimate reflects the relative abundance of fruit availability in areas where bird abundance was monitored (Solórzano et al. 2000). Sampling efforts (number of hours devoted to counting birds) varied among sampling periods due to the rain. Thus, we used the number of birds per sampling hour as an estimate of bird abundance.

\section{Results}

Temporal and spatial patterns in umbrellabird abundance

We registered 32 sightings of umbrellabirds along the altitudinal gradient in 171.6 hours of sampling (Appendix 1). Calls of males indicated the beginning and conclusion of the breeding season (Snow 1982, Stiles and Skutch 1989). Temporal and spatial changes of abundance were consistent with the expected altitudinal migration pattern: umbrellabirds occurred at higher elevation sites during the breeding season (March-June, Figure 2A-C), and at lower elevation sites during the non-breeding season (Figure 2D).

We did not record umbrellabirds during the non-breeding season in the highlands $(1,400$ and $1,000 \mathrm{~m})$ or during the breeding season in the lowlands $(400 \mathrm{~m})$. However, at middle elevations the pattern was not clear. We found umbrellabirds at $800 \mathrm{~m}$ between January and June, as expected in a premontane forest at this elevation (Fogden and Fogden 1997), but we recorded the species again in November. The January-June birds showed signs of breeding activity indicating that they were reproductive individuals. After June these birds were not seen or heard again. Birds recorded in November were probably transients from higher elevations (individuals that spent the breeding season above $800 \mathrm{~m}$ ) that were migrating to the lowlands (Loiselle and Blake 1991).

Transects for surveying umbrellabirds in the tropical wet forest crossed the border between the protected and unprotected forested area. All umbrellabirds recorded on these transects were within the borders or outside the protected area.

\section{Movements of radio-tagged birds}

Radio-telemetry data supported the information generated from transects, which suggested that umbrellabirds spent the non-breeding season outside the protected area. We caught two individuals (males) in approximately 500 mist-net hours of sampling (the low capture rate possibly due to low density of birds in 

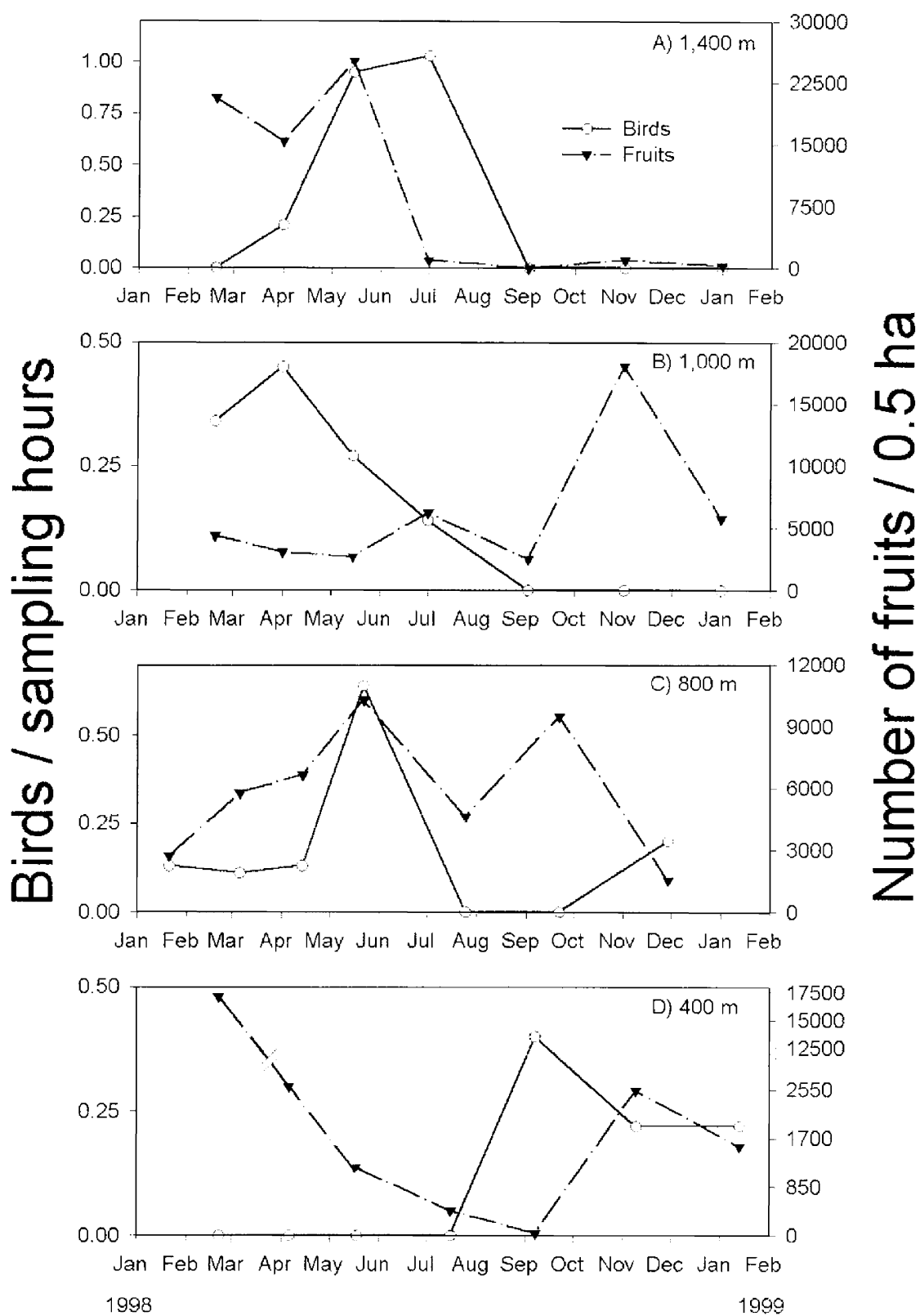

Figure 2. Temporal abundance of Bare-necked Umbrellabird and fruits consumed by this species at four different elevations on the Tilarán Mountains, Costa Rica during 19981999. Elevations represent (A) lower montane rainforest ( $1,400 \mathrm{~m})$, (B) premontane rainforest $(1,000 \mathrm{~m}),(\mathrm{C})$ premontane rainforest $(800 \mathrm{~m})$ and $(\mathrm{D})$ tropical wet forest cool transition $(400 \mathrm{~m})$. 
the area; Fogden and Fogden 1997). The birds remained in their reproductive area (the 1,400 m site) from early March to late June 1998. After June, both birds disappeared from their breeding grounds (of this elevation) and were not detected again in the study area until November. In this month, both birds were found outside the protected area, close to the border between the forested and deforested areas (Figure 3). This border was at $600-700 \mathrm{~m}$ and corresponded to the limit between premontane rainforest and tropical wet forest cool transition life zones (Haber 2000).

In March 1999, both males were observed without the harnesses and radiotransmitters (identified by colour bands) approximately $100 \mathrm{~m}$ away from the area where they were caught in 1998. In fact, one of the males was colour-banded in the same area in 1997, and returned to the same tree for two consecutive years. The radio-transmitters were later detected inside the protected area; therefore, it was not possible to determine how long the birds remained outside the reserve complex. Nevertheless, this information suggests that the males were not negatively affected by the radio-transmitter and harness.

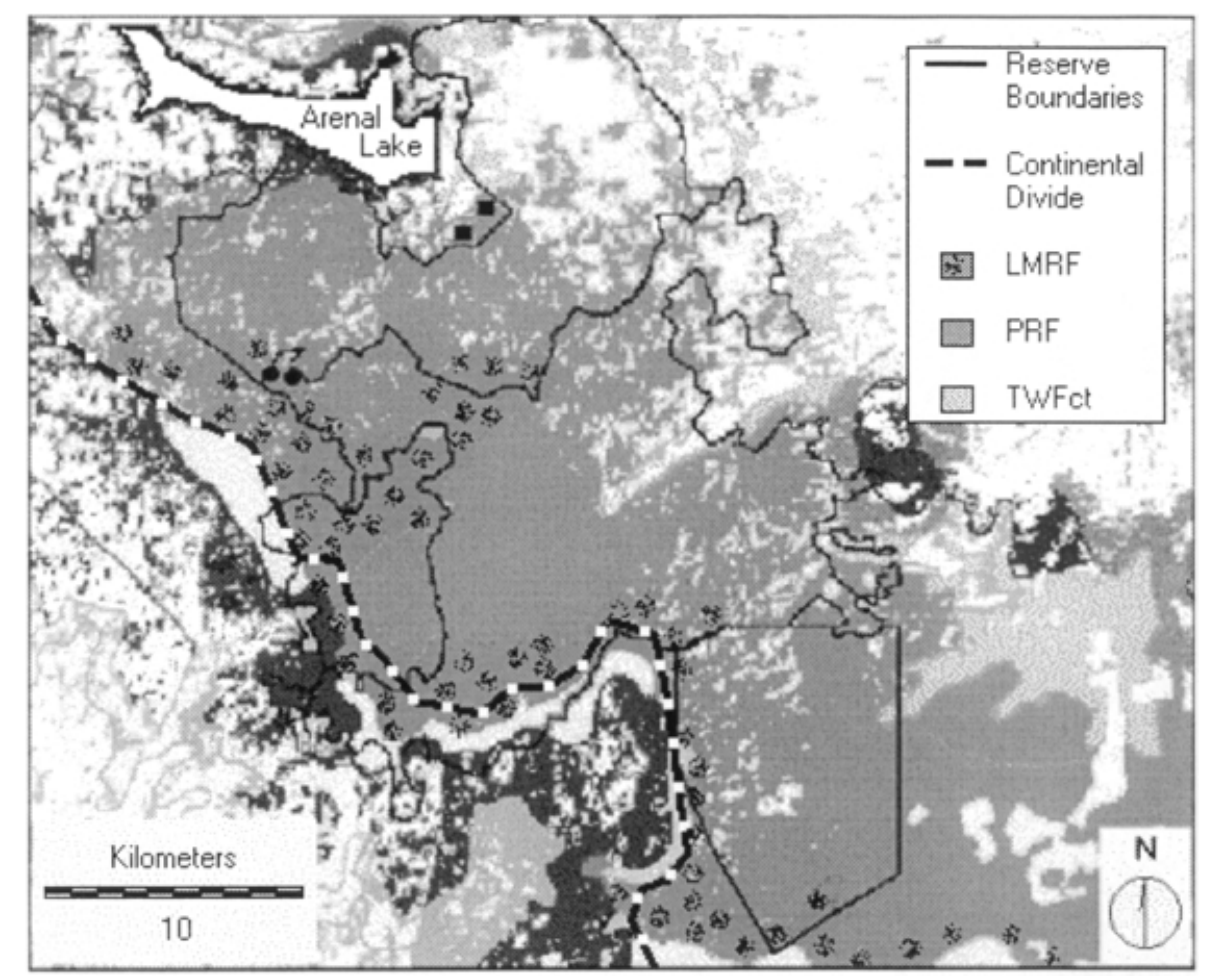

Figure 3. Movements of two radio-tagged umbrellabirds from breeding areas (circles) to non-breeding areas (squares) and vice versa on the Caribbean slope of Tilarán Mountains, Costa Rica. 1998-1999. Deforested areas are shown in white. Forested areas on the Caribbean slope are shown according to Holdridge life zones as follows: LMRF, lower montane rainforest; PRF, premontane rainforest; TWFct, tropical wet forest cool transition. 


\section{Relationships between fruit abundance and umbrellabird abundance}

The study transects included 75 trees of 23 genera whose fruits were consumed (or potentially consumed) by umbrellabirds (Appendix 2). Fruit abundance varied temporally and spatially along the altitudinal gradient. At 1,400 $\mathrm{m}$ there was a pronounced peak between February and April, and at 1,000 $\mathrm{m}$ there were more fruits during October-November (Figure 2A, B). Fruit abundance did not show pronounced peaks at $800 \mathrm{~m}$, but there were fewer fruits at the beginning and at the end of 1998 (Figure $2 \mathrm{C}$ ). In contrast, at $400 \mathrm{~m}$, fruit abundance was clearly higher between February and April 1998 and October 1998 to January 1999 with respect to other months (Figure 2D).

At the $1,400 \mathrm{~m}$ site the period of fruit abundance partially coincided with the period of presence of umbrellabirds (Figure 2A). When fruit abundance decreased at this elevation umbrellabirds were absent from the site. Nevertheless, there was not a significant correlation between fruit and bird abundance. Since it is possible that a "time lag" existed between a decrease in fruit abundance and bird movements (Ortiz-Pulido et al. 2000), we performed a dephased correlation (one sampling period "backward" in the case of bird abundance), which resulted in a highly significant relationship between bird and fruit abundance $\left(r_{\mathrm{s}}=0.81\right.$, $n=7, P=0.03)$. This suggests that birds moved around a month after fruit abundance decreased.

In the tropical wet forest $(400 \mathrm{~m})$, the period of high fruit abundance partially overlapped (between November and January) with bird presence (Figure 2D). Nevertheless, the highest production of fruits occurred in February when birds seemed to be absent from the site. We did not find a significant correlation between bird and fruit abundance even when taking into account a "time lag" effect. The inclusion of "potentially" consumed fruits in this lowland site could have added "noise" to the possible relationship.

At intermediate elevations ( 1,000 and $800 \mathrm{~m}$ ), fruit abundance did not coincide (even partially) with bird presence or abundance (Figure 2B, C). Accordingly, we did not find significant correlations between bird and fruit abundance, even considering the possibility of "time lags".

\section{Discussion}

The data suggested that umbrellabird populations moved from highlands to lowlands and vice versa, as was proposed by Stiles $(1985,1988)$, and supported previous observations that male umbrellabirds return to the same breeding area every year (Fogden and Fogden 1997). The results of this study also indicated that within the Tilarán Mountain range umbrellabirds migrated from high elevations where they breed to the lowest possible elevations where forest still remains. In their downward movements at least some of these birds moved out of the protected area, to contiguous forested areas below the reserve boundaries. The presence of Bare-necked Umbrellabirds in the highest and lowest elevations partially corresponded to periods of highest abundance of the type of fruits this species consumed. This suggested they depend (at least partially) on these fruiting plants during both the breeding and non-breeding seasons, as has been proposed for other large fruit-eating species (Snow 1961, 1970, Wheelwright 
1983). The absence of any relationship at intermediate elevations may be because high elevations are more favourable places to breed than intermediate elevations. Additional studies that take into account energy intake of fruits and animal food should be conducted to evaluate this hypothesis.

At present, the protected area on the Caribbean slope of the Tilarán Mountains mostly encompasses montane and premontane forest (Burlingame 2000, Powell et al. 2000). As of 1999, the protected area on the Caribbean slope extended from the continental divide to $650 \mathrm{~m}$, which corresponds to the premontane rainforest life zone (Retamosa 1999, Blake and Loiselle 2000, Haber 2000, Nadkarni and Wheelwright 2000). Therefore, the life zone where umbrellabirds spent the breeding season seems adequately protected. However, some umbrellabirds spent the non-breeding season in the tropical wet forest cool transition life zone, and only a few parts of the reserves encompass this life zone at 400-500 m (Powell et al. 2000). According to Retamosa (1999), the area protected below $800 \mathrm{~m}$ (i.e. tropical wet forest cool transition) constitutes at most $20 \%$ of the area where umbrellabirds are expected to occur during the non-breeding season. Therefore, the life zone that umbrellabirds use during the non-breeding season is mostly unprotected (Figure 3).

If logging continues in the lowlands of the Tilarán Mountains, the habitat that provides food for umbrellabirds during the non-breeding season could be totally destroyed. The lowest elevations that are currently protected in this area are premontane rainforest (around $700 \mathrm{~m}$ ), and fruit abundance in this life zone was low during the non-breeding season (Figure $2 \mathrm{C}$ ). This pattern has been detected in other phenological studies at similar elevations in the premontane rainforest life zone on the Caribbean slope of Costa Rica (Loiselle and Blake 1991, Rosselli 1994). Consequently, it seems probable that the lowest elevations of premontane rainforest might not provide enough food for umbrellabird populations during the non-breeding season, if tropical wet forest cool transition areas were to disappear.

Umbrellabird movements outside the protected area suggest that this species formerly migrated to lower elevations than it does today in the Tilarán Mountains, probably to the tropical wet forest life zone (o-400 m), as occurs on the Cordillera Central of Costa Rica (Slud 1960, Loiselle 1988, Stiles and Levey 1994). Tropical wet forest formerly covered a large area of the lowlands at the base of the Tilarán Mountains (Tosi 1969), but at present it is practically non-existent in this area. The period of highest fruit production in tropical wet forest occurred during the umbrellabirds' non-breeding season (roughly between August-February; Frankie et al. 1974, Opler et al. 1980, Levey 1988, Loiselle and Blake 1991, Levey et al. 1994) as we detected in the tropical wet forest cool transition life zone. Consequently, the destruction of tropical wet forest could have led to a reduction in food available for umbrellabirds during the non-breeding season.

The decline in area of habitat available in the lowlands of Costa Rica and Panama has probably caused a decrease in Bare-necked Umbrellabird populations (BirdLife International 2000). Changes in natural environments generally increase the rate of extinction of birds (Steadman 1997) by making them more sensitive to catastrophes, or genetic and demographic stochasticities (Lande 1993). In 1997, the population of umbrellabirds in the protected area of the Tilarán Mountains (Peñas Blancas river valley) was estimated at less than 60 indi- 
viduals (Fodgen and Fogden 1997). Thus, the forest in the tropical wet forest cool transition zone that still remains on the Tilarán Mountains could be critical for the conservation of the species and should be totally protected.

The study of altitudinal movements of Resplendent Quetzal Pharomachrus mocinno recently triggered the expansion of the lower limits of the protected area (specifically the Children's Eternal Rainforest) in the Caribbean slope of the Monteverde region (Powell and Bjork 1995). Nevertheless, the present study suggests that additional expansion of the protected area into the lowlands toward the Caribbean slope is necessary to enhance the conservation prospects of Barenecked Umbrellabird.

Bare-necked Umbrellabird depends on areas of continuous forest (Stiles 1985). For this reason, forest corridors should be promoted in the fragmented forest below $800 \mathrm{~m}$ on the Tilarán Mountains if the species is to be conserved in this area. The expansion of the protected area could also protect other altitudinal migrants that spend the non-breeding season in forest below $400 \mathrm{~m}$ (at least 16 other species; see Blake and Loiselle 2000), as well as resident species of these elevations (Loiselle and Blake 1991, Young et al. 1998, Blake and Loiselle 2000). Protecting the habitat of Bare-necked Umbrellabird will likely protect many other species, not necessarily birds, which use those habitats as well (Wheelwright 2000).

\section{Acknowledgements}

We are very grateful to G. Barrantes who provided comments, discussions and advice throughout this research project. G. Ávalos, F. Bolaños, F. Joyce, S. Buckton, and D. C. Wege provided useful comments and suggestions that improved earlier drafts of this paper. Special thanks to A. Alvarado and H. Ramírez, our indefatigable field assistants. Work at Alberto Ml. Brenes Biological Reserve was possible due to the logistical support of R. Ortiz. R. Carlson granted permission to work in the Monteverde Cloud Forest Preserve. R. Valverde, P. Aguilar, M. Retamosa, and T. Chavarría provided considerable field assistance too. J. GómezLaurito, V. Mora, J. Torres, W. Alfaro, and R. Salas identified most of the plants. Thanks to W. A. Haber for valuable descriptions that led us to the identification of Coussapoa contorta. J. F. Fossani and A. M. Class gently provided invaluable assistance in the preparation of the English version. This research constitutes partial fulfilment of the requirements for a Master's degree in Biology (J.C.) at the University of Costa Rica. The Monteverde Conservation League provided research support through a grant from the British Embassy.

Appendix 1. Number of hours devoted to counting and the number of umbrellabirds recorded during 1998-1999 at four different elevations on the Cordillera de Tilarán, Costa Rica. Elevations represent lower montane rainforest $(1,400 \mathrm{~m})$, premontane rainforest $(1,000 \mathrm{~m}$ and $800 \mathrm{~m})$, and tropical wet forest cool transition (400 m).

\begin{tabular}{llll}
\hline Elevation & Date & Sampling hours & Birds \\
\hline 1,400 m & 31 Jan 98 & 10.39 & 0 \\
& 20 Mar 98 & 4.83 & 1 \\
& 25 Apr 98 & 3.17 & 3 \\
& 14 Jun 98 & 3.89 & 4 \\
\hline
\end{tabular}


Appendix 1. Continued.

\begin{tabular}{|c|c|c|c|}
\hline Elevation & Date & Sampling hours & Birds \\
\hline & 1 Aug 98 & 3.98 & o \\
\hline & 5 Oct 98 & $4 \cdot 34$ & o \\
\hline & 20 Dec 98 & 3.25 & o \\
\hline \multirow[t]{7}{*}{$1,000 \mathrm{~m}$} & 18 Feb 98 & 11.67 & 4 \\
\hline & 1 Apr 98 & $4 \cdot 40$ & 2 \\
\hline & 15 May 98 & $7 \cdot 42$ & 2 \\
\hline & 1 Jul 98 & 7.25 & 1 \\
\hline & 2 Sep 98 & 4.66 & o \\
\hline & I Nov 98 & 5.13 & o \\
\hline & 1 Jan 99 & 6.00 & o \\
\hline \multirow[t]{7}{*}{$800 \mathrm{~m}$} & 21 Jan 98 & 7.75 & 1 \\
\hline & 6 Mar 98 & 8.84 & 1 \\
\hline & 14 Apr 98 & 7.67 & 1 \\
\hline & 22 May 98 & 11.00 & 7 \\
\hline & $25 \mathrm{Jul} 98$ & 8.00 & o \\
\hline & 22 Sep 98 & 4.75 & o \\
\hline & 29 Nov 98 & 5.00 & 1 \\
\hline \multirow[t]{7}{*}{$400 \mathrm{~m}$} & 21 Feb 98 & 6.83 & o \\
\hline & 6 Apr 98 & 5.98 & o \\
\hline & 18 May 98 & $5 \cdot 33$ & o \\
\hline & $16 \mathrm{Jul} 98$ & 5.89 & o \\
\hline & 7 Sep 98 & 5.00 & 2 \\
\hline & 9 Nov 98 & 4.58 & 1 \\
\hline & 13 Jan 99 & 4.58 & 1 \\
\hline
\end{tabular}

Appendix 2. Plants consumed by Bare-necked Umbrellabird that produced fruits during 1998-1999 on the Tilarán Mountains, Costa Rica.

\begin{tabular}{|c|c|}
\hline Family & Genus / species \\
\hline Annonaceae & Guatteria \\
\hline Arecaceae & Euterpe \\
\hline Arecaceae & Prestoea \\
\hline Arecaceae & Iriartea deltoidea \\
\hline Burseraceae & Protium costaricense ${ }^{\mathrm{a}}$ \\
\hline Cecropiaceae & Coussapoa contorta \\
\hline Chrysobalanaceae & Licania $^{\mathrm{a}}$ \\
\hline Euphorbiaceae & Croton $^{\mathrm{a}}$ \\
\hline Flacourtiaceae & Lunania mexicana ${ }^{\mathrm{a}}$ \\
\hline Lauraceae & Ocotea \\
\hline Lauraceae & Nectandra \\
\hline Marcgraviaceae & Margravia affinis \\
\hline Melastomataceae & Conostegia oersterdiana \\
\hline Meliaceae & Guarea \\
\hline Moraceae & Ficus \\
\hline Moraceae & Sorocea $^{\mathrm{a}}$ \\
\hline Papilionaceae & Swartzia simplex $x^{a}$ \\
\hline Rhamnaceae & Colubrina spinosa ${ }^{\mathrm{a}}$ \\
\hline Rubiaceae & Guettarda \\
\hline Rubiaceae & Psychotria \\
\hline Sapotaceae & Chrysophyllum hirsutum \\
\hline Sapotaceae & Pouteria \\
\hline
\end{tabular}

${ }^{\text {a }}$ Fruit potentially consumed in tropical wet forest cool transition (see text). 


\section{References}

BirdLife International (2000) Threatened birds of the world. Barcelona and Cambridge, U.K.: Lynx Edicions and BirdLife International.

Blake, J. G. and Loiselle B. A. (1991) Variation in resource abundance affects capture rates of birds in three lowland habitats in Costa Rica. Auk 108: 114-130.

Blake, J. G. and Loiselle B. A. (2000) Diversity of birds along an elevational gradient in the Cordillera Central, Costa Rica. Auk 117: 663-686.

Blake, J. G., Loiselle, B. A., Moermond, T. C., Levey, D. J. and Denslow, J. S. (1990a) Quantifying abundance of fruits for birds in tropical habitats. Stud. Avian Biol. 13: 73-79.

Blake, J. G., Stiles, F. G. and Loiselle, B. A. (1990b) Birds of La Selva Biological Station: habitat use, trophic composition, and migrants. Pp. 161-182 in A. Gentry, ed. Four Neotropical rain forests. New Haven: Yale University Press.

Burlingame, L. J. (2000) Conservation in the Monteverde zone: contributions of conservation organizations. Pp. $351-385$ in N. M. Nadkarni and N. T. Wheelwright, eds. Monteverde. Ecology and conservation of a tropical cloud forest. New York: Oxford University Press.

Clark, K. L., Lawton, R. O. and Butler, P. R. (2000) The physical environment. Pp. 15-38 in N. M. Nadkarni and N. T. Wheelwright, eds. Monteverde. Ecology and conservation of a tropical cloud forest. New York: Oxford University Press.

Coen, E. (1983) Climate. Pp. 35-46 in D.H. Janzen, ed. Costa Rican natural history. Chicago: University of Chicago Press.

Collar, N. J., Gonzaga, L. P., Krabbe, N., Madroño, A., Naranjo, L.G., Parker, T. A. and Wege, D. C. (1992) Threatened birds on the Americas: the ICBP/IUCN Red Data Book. Third edition, part 2. Washington, D.C. and Cambridge, U.K.: Smithsonian Institution Press and International Council for Bird Preservation.

Dinerstein, E. (1986) Reproductive ecology of fruit bats and the seasonality of fruit production in a Costa Rican cloud forest. Biotropica 18: 307-318.

Fogden, M. P. (2000) Birds of the Monteverde area. Pp. 541-552 in N. M. Nadkarni and N. T. Wheelwright, eds. Monteverde. Ecology and conservation of a tropical cloud forest. New York: Oxford University Press.

Fogden, M. P. and Fogden, P. M. (1997) Notes on the behaviour of Bare-necked Umbrellabird Cephalopterus glabricollis in the Monteverde Cloud Forest Preserve, Costa Rica. Cotinga 8: 23-26.

Frankie, G. W., Baker, H. G. and Opler, P. A. (1974) Comparative phenological studies of trees in tropical wet and dry forest in the lowlands of Costa Rica. J. Ecol. 62: 881-919.

Haber, W. A. (2000) Plants and vegetation. Pp. 39-70 in N. M. Nadkarni and N. T. Wheelwright, eds. Monteverde. Ecology and conservation of a tropical cloud forest. New York: Oxford University Press.

Holdridge, L. R. (1967) Life zone ecology. Revised edition. San José, Costa Rica: Tropical Science Center.

Lande, R. (1993) Risks of population extinction from demographic and environmental stochasticity, and random catastrophes. Am. Nat. 142: 911-927.

Levey, D. J. (1988) Spatial and temporal variation in Costa Rican fruit and fruit-eating bird abundance. Ecol. Monogr. 58: 251-269.

Levey, D. J., Moermond, T. C. and Denslow, J. S. (1994) Frugivory: an overview. Pp 282294 in L. A. McDade, K. S. Bawa, H. A. Hespenheide and G. S Hartshorn, eds. La Selva. Ecology and natural history of a neotropical rain forest. Chicago: University of Chicago Press.

Loiselle, B. A. (1988) Bird abundance and seasonality in a Costa Rican lowland forest canopy. Condor 90: 761-772.

Loiselle, B. A. and Blake, J. G. (1991) Temporal variation in birds and fruits along an elevational gradient in Costa Rica. Ecology 72: 180-193. 
Loiselle, B. A. and Blake, J. G. (1992) Population variation in a tropical bird community. Implications for conservation. BioScience 42: 838-845.

Nadkarni, N. M. and Wheelwright, N. T. (2000) Introduction. Pp. 3-13 in N. M. Nadkarni and N. T. Wheelwright, eds. Monteverde. Ecology and conservation of a tropical cloud forest. New York: Oxford University Press.

Opler, P. A., Frankie G. W. and Baker H. G. (1980) Comparative phenological studies of treelet and shrub species in tropical wet and dry forests in the lowlands of Costa Rica. J. Ecol. 68: 167-188.

Ortiz-Pulido, R., Laborde, J. and Guevara, S. (2000) Frugivoría por aves en un paisaje fragmentado: consecuencias en la dispersión de semillas. Biotropica 32: 473-488.

Powell, G.V.N and Bjork, R. (1995) Implications of intratropical migration on reserve design: a case study using Pharomachrus mocinno. Conserv. Biol. 9: 354-362.

Powell, G.V.N, Bjork, R. D., Barrios, S. and Espinoza, V. (2000) Elevational migrations and habitat linkages: using the Resplendent Quetzal as an indicator for evaluating the design of Monteverde Reserve Complex. Pp. 439-442 in N. M. Nadkarni and N. T. Wheelwright, eds. Monteverde. Ecology and conservation of a tropical cloud forest. New York: Oxford University Press.

Retamosa, M. (1999) Factores que determinan la presencia de pájaros sombrilla (Cephalopterus glabricollis, Cotingidae) machos en hábitats de Bosque premontano de la Cordillera de Tilarán, Costa Rica. Heredia, Costa Rica: Universidad Nacional (M.Sc. thesis).

Ridgely, R. S. and Gwynee, G. A. (1993) Guía de las aves de Panamá incluyendo Costa Rica, Nicaragua y Honduras. 1ra. ed. Colombia: ANCON.

Rosselli, L. (1994) The annual cycle of the White-ruffed Manakin Corapipo leucorrhoa, a tropical frugivorous altitudinal migrant, and its food plants. Bird Conserv. Internatn. 4: 143-160.

Sanford, R. L., Paaby, P., Luvall, J. C. and Phillips, E. (1994) Climate, geomorphology, and aquatic systems. Pp. 19-33 in L. A. McDade, K. S. Bawa, H. A. Hespenheide and G. S Hartshorn, eds. La Selva. Ecology and natural history of a Neotropical rain forest. Chicago: University of Chicago Press.

Slud, P. (1960) The birds of finca "La Selva", a tropical wet forest locality. Bull. Am. Mus. Nat. Hist.121: 49-148.

Snow, B. K. (1970) A field study of the Bearded Bellbird in Trinidad. Ibis 112: 299-329.

Snow, D. W. (1961) The natural history of the oilbird, Steatornis caripensis, in Trinidad, West Indies. Part 1. Zoologica 46: 27-46.

Snow, D. W. (1982) The Cotingas. Ithaca, NY: Cornell University Press.

Solórzano, S., Castillo, S. and Valverde, T. (2000) Quetzal abundance in relation to fruit availability in a cloud forest in southeastern Mexico. Biotropica 32: 523-532.

Steadman, D. W. (1997) Human-caused extinction of birds. Pp. 139-161 in M. L. ReakaKudla, D. E. Wilson and E. O. Wilson, eds. Biodiversity II. Washington D.C.: Joseph Henry Press.

Stiles, F. G. (1985) Conservation of forest birds in Costa Rica: problems and perspectives. Pp. 141-168 in A. W. Diamond and T. E. Lovejoy, eds. Conservation of tropical forest birds. Cambridge, U.K.: International Council for Bird Preservation.

Stiles, F. G. (1988) Altitudinal movements of birds on the Caribbean slope of Costa Rica: implications for conservation. Pp. $243-258$ in F. Almeda and C. M. Pringle, eds. Tropical rain forest: diversity and conservation. San Francisco: California Academy of Sciences.

Stiles, F. G. and Levey, D. J. (1994) Birds of La Selva and vicinity. Pp. 384-393 in L. A. McDade, K. S. Bawa, H. A. Hespenheide and G. S Hartshorn, eds. La Selva. Ecology and natural history of a neotropical rain forest. Chicago: University of Chicago Press.

Stiles, F. G. and Skutch, A. F. (1989) A guide to the birds of Costa Rica. Ithaca, NY: Cornell University Press. 
Terborgh, J. (1992) Perspectives on the conservation of Neotropical migrant landbirds. Pp. $7^{-12}$ in J. M. Hagan and D. W. Johnston, eds. Ecology and conservation of neotropical migrant landbirds. Washington D.C: Smithsonian Institution Press.

Tosi, J. A. (1969) Mapa ecológico, República de Costa Rica: Según la clasificación de zonas de vida del mundo de L. R. Holdridge. San José, Costa Rica: Centro Científico Tropical.

Wheelwright, N. T. (1983) Fruits and the ecology of Resplendent Quetzals. Auk 100: 286301.

Wheelwright, N. T. (1991) How long do fruit-eating birds stay in the plants where they feed? Biotropica 23: 29-40.

Wheelwright, N. T. (2000) Conservation biology. Pp. 419-432 in N. M. Nadkarni and N. T. Wheelwright, eds. Monteverde. Ecology and conservation of a tropical cloud forest. New York: Oxford University Press.

Young, B. E, DeRosier, D. and Powell, G.V.N. (1998) Diversity and conservation of understory birds in the Tilarán Mountains, Costa Rica. Auk 115: 998-1016.

\section{JOHEL CHAVES-CAMPOS ${ }^{1}$}

Escuela de Biología, Universidad de Costa Rica, San Pedro de Montes de Oca, San José, Costa Rica. Email: jchavesc@costarricense.cr

J. EDGARDO ARÉVALO

Monteverde Conservation League, Apartado Postal 10581-1000, San José, Costa Rica.

MARIAMALIA ARAYA

Tirimbina Rainforest Center, SarapiquP, Costa Rica.

${ }^{1}$ Corresponding author.

Received 31 January 2002; revision accepted 26 September 2002 